\title{
Effect of Astragalus membranaceus (Fisch) Bunge extract on streptozocin-induced diabetic in rats
}

\author{
Mei-ling Huo ${ }^{1,2}$, Kai Yuan ${ }^{3}$, Xiang-rong Liang ${ }^{2}, \mathrm{Hua} \mathrm{Li}^{2}$ and Gui-mei $\mathrm{Li}^{1 *}$ \\ ${ }^{1}$ Department of Pediatrics, Shandong Provincial Hospital Affiliated to Shandong University, Jinan. Shangdong 250014, \\ ${ }^{2}$ Department of Pediatrics, Qilu Children's Hospital, Shandong University, Jinan, Shangdong 250022, ${ }^{3}$ Department of General \\ Surgery, Shandong Provincial Qianfoshan Hospital, Shandong University, Jinan, Shangdong, 250014, China
}

*For correspondence: Email: liguimei133494@163.com; Tel: +86 053187938911

Received: 10 August 2015

Revised accepted: 13 June 2016

\begin{abstract}
Purpose: To investigate the effect of Astragalus membranaceus (Fisch.) Bunge. extract (AMBE) on streptozotocin-induced diabetic rats.

Methods: The aqueous extract of $A M B$ was obtained by steeping the dried Astragalus membranaceus (Fisch.) Bunge. in water at $60{ }^{\circ} \mathrm{C}$ three times, each for $1 \mathrm{~h}$, before first drying in an oven at $100{ }^{\circ} \mathrm{C}$ and then freeze-drying the last extract thus obtained. Diabete model rats was induced by a single intraperitoneal injection of a freshly prepared solution of streptozotocin (50 $\mathrm{mg} / \mathrm{kg}$ ). The rats were randomly divided into 6 groups of ten rats each: negative control group, normal control group, reference group (glibenclamide1 mg/kgbody weight) as well as AMB extract groups, namely, 40, 80 and 160 $\mathrm{mg} / \mathrm{kg}$ body weight. Antihyperglycemic effect was measured by blood glucose and plasma insulin levels. Oxidative stress was evaluated in liver and kidney by antioxidant markers, viz, lipidperoxidation (LPO), superoxide dismutase (SOD), reduced glutathione (GSH), glutathione peroxidase (GPx) and catalase (CAT), while blood serum levels of creatinine and urea were also determined in both diabetic control and treated rats.

Results: Compared with diabetic rats, oral administration of AMBE at a concentration of $160 \mathrm{mg} / \mathrm{kg}$ daily for 30 days showed a significant decrease in fasting blood glucose $(109.438 \pm 3.52, p<0.05)$ and increased insulin level (13.96 $\pm 0.74, p<0.05)$. Furthermore, it significantly reduced biochemical parameters (serum creatinine, $0.86 \pm 0.29, p<0.05)$ and serum urea $(45.14 \pm 1.79, p<0.05)$. The treatment also resulted in significant increase in GSH (49.21 $\pm 2.59, p<0.05)$, GPx (11.96 $\pm 1.16, p<$ $0.05)$, SOD (14.13 $\pm 0.49, p<0.05)$, CAT (83.25 $\pm 3.14, p<0.05)$ level in the liver and kidney of diabetic rats.

Conclusion: The results suggest that $A M B E$ may effectively normalize impaired antioxidant status in streptozotocin-induced diabetes in a dose-dependent manner. AMBE has a protective effect against lipid peroxidation by scavenging free radicals and is thus capable of reducing the risk of diabetic complications.
\end{abstract}

Keywords: Astragalus membranaceus, Diabetic, Antihyperglycemic, Antioxidant Oxidative stress, Fasting blood glucose

Tropical Journal of Pharmaceutical Research is indexed by Science Citation Index (SciSearch), Scopus, International Pharmaceutical Abstract, Chemical Abstracts, Embase, Index Copernicus, EBSCO, African Index Medicus, JournalSeek, Journal Citation Reports/Science Edition, Directory of Open Access Journals (DOAJ), African Journal Online, Bioline International, Open-J-Gate and Pharmacy Abstracts

\section{INTRODUCTION}

Diabetes mellitus, a metabolic disorder characterized by hyperglycemia, dyslipidemia, insulin resistance, insufficient insulin secretion, is a major public health problem in developing and developed countries. The increase in diabetic cases has been partly attributed to consumption 
of calorie-rich diet, obesity and sedentary life style [1]. Developed countries such as India, China and the United States of America are presently the countries with the leading number of diabetics. Furthermore, seven percent of residents of the United States are diabetic.

Though diabetes is a non-communicable disease, it is considered to be one of the five leading causes of death in the world [2]. The disease is a complex metabolic disorder of the endocrine system with dynamic expression of pathological disequilibria, resulting in various micro and macro vascular complications. It is characterized by high blood glucose levels (hyperglycemia) due to the inability of the body's cells to utilize glucose properly [3].

The increased blood glucose levels in diabetes produce superoxide anions, which generate hydroxyl radicals via Haber-Weiss reaction, resulting in peroxidation of membrane lipids and protein glycation. This leads to oxidative damage of cell membranes. These radicals further damage other important biomolecules including carbohydrates, proteins and deoxyribonucleic acid (DNA) [4].

In diabetes, oxidative stress has been found mainly due to an increased production of oxygen free radicals and a sharp reduction of antioxidant defenses [5]. The endogenous antioxidant enzymes (e.g., SOD, CAT, GSH and GPx) are responsible for the detoxification of deleterious oxygen radicals [6]. Antioxidants thus play an important role to protect the human body against damage caused by reactive oxygen species [4]. Hence, compounds with both hypoglycemic and antioxidative properties would be useful antidiabetic agents [7].

Medicinal plants are widely used by the population of developing countries as alternative therapy. In China, hundreds of plants are used traditionally for the management of diabetes mellitus. Unfortunately, only a few of such Chinese medicinal plants have received scientific scrutiny. Despite the long traditional use of Astragalus membranaceus (Fisch.) Bunge.

In diabetes $[8,9]$, no systematic pharmacological work has been carried out on this plant. The present study was therefore designed to study the antioxidant potential and hypoglycemic effect of Astragalus membranaceus (Fisch.) Bunge. extract against streptozotocin induced diabetic rats.

\section{EXPERIMENTAL}

\section{Plant material and extraction}

Samples of Astragalus membranaceus (Fisch.) Bunge. were collected from Bozhou City, Anhui Province in China in May 2015. Taxonomic identification of the plant was performed by Professor Jun-li Meng of Shandong University in China. A voucher specimen (no. AMB 20150402) was deposited in the herbarium of College of Pharmacy, Shandong University, China for future reference.

The whole plant of Astragalus membranaceus (Fisch.) Bunge. was dried in a drying oven at 100 ${ }^{\circ} \mathrm{C}$ for $12 \mathrm{~h}$. The aqueous extract of $\mathrm{AMB}$ was obtained by steeping the dried Astragalus membranaceus (Fisch.) Bunge. in water at $60{ }^{\circ} \mathrm{C}$ three times, each for $1 \mathrm{~h}$ before first drying in an oven and then freeze-drying the last extract thus obtained. One gram powder was obtained from about $1.5 \mathrm{~g}$ dried sample, i.e., a yield of $66.7 \%$.

\section{Animals}

SPF Male Wistar rats, weighing 180 - $200 \mathrm{~g}$, were provided by the Experimental Animal Center of Shandong Province (Certificate no. SYXK2005 - 0002). The animals had free access to food and water, and were allowed to acclimatize for at least one week before use. The rat experiment was approved by the Animal Care and Use Committee of Shandong University (approval ref no. 20101004) and was carried out in compliance with Directive 2010/63/EU on the handling of animals used for scientific purposes [10].

\section{Animal groups}

The rats were randomly divided into 6 groups of ten rats each: negative control group, control group, reference group (glibenclamide $1 \mathrm{mg} / \mathrm{kg}$ body weight) as well as AMB extract groups, namely, 40, 80 and $160 \mathrm{mg} / \mathrm{kg}$ body weight. Treatments (in aqueous solution) were given orally once daily for 30 days.

\section{Induction of experimental diabetes}

The animals were fasted overnight and diabetes was induced by a single intraperitoneal injection of a freshly prepared solution of streptozotocin (50 mg/kg) in citrate buffer $(\mathrm{pH} \mathrm{4.5)} \mathrm{[11].} \mathrm{The}$ animals were allowed to drink $5 \%$ glucose solution to overcome the drug induced hypoglycemia [12]. On the third day of STZinjection, the rats were fasted for $6 \mathrm{~h}$ and blood was withdrawn by retroorbital puncture under 
ether anesthesia. Rats with moderate diabetes having hyperglycemia (that is, with blood glucose of $250-400 \mathrm{mg} / \mathrm{dl}$ ) were taken for the experiment [13].

\section{Biochemical analysis}

Rats were fasted overnight and the blood was withdrawn by retro orbital puncture under light ether anesthesia on the days 1, 15 and 30 postinduction to determine blood glucose and plasma insulin level. The change in body weight was observed throughout treatment period in the experimental animals. At the end of 30 days, the animals were deprived of food overnight and sacrificed by cervical decapitation for biochemical parameters (hemoglobin, glycosylated $\mathrm{Hb}$, total protein, serum creatinine, serum urea) and antioxidant enzyme (SOD, CAT, GSH, GPx, LPO) estimation. Blood was collected from the heart in two different tubes, i.e. one with anticoagulant for plasma, and another without anticoagulant for serum separation. Serum was separated by centrifugation $3500 \mathrm{rpm}$ at $25{ }^{\circ} \mathrm{C}$ for $10 \mathrm{~min}$. Fasting blood glucose was estimated by O-toluidine method [14]. Plasma insulin level was assayed by the radio-immunoassay method. All other biochemical tests were carried out in our lab by using commercial kits obtained from Erba diagnostic Mannheim Gmbh, Germany.

\section{Oral glucose tolerance test}

The rats were divided into four groups of 6 animals $(n=6)$ each. Group I served as control and received distilled water. Group II served as diabetic control and received distilled water. Group III served as positive control, received glibenclamide (1 $\mathrm{mg} / \mathrm{kg})$. Group IV received AMBE $80 \mathrm{gm} / \mathrm{kg}$ orally. The rats were fasted for $18 \mathrm{~h}$ and the test performed by oral administration of glucose $(2 \mathrm{~g} / \mathrm{kg})$ to diabetic and normal rats $30 \mathrm{~min}$ after dosing. Blood samples were collected from the retro-orbital plexus of the eye (under light ether anesthesia) immediately (0 h), 30, 60, 90, and $120 \mathrm{~min}$ after the glucose administration and the blood glucose levels were estimated.

\section{Assay of antioxidant enzyme}

The liver and kidney were carefully removed, weighed and washed in ice-cold saline to remove the blood. Then both were sliced separately into pieces and homogenized with buffer containing $0.25 \mathrm{M}$ sucrose and $0.1 \mathrm{M}$ Tris $\mathrm{HCl}$ buffer $(\mathrm{pH}$ 7.4). The homogenate was centrifuged at 3000 rpm for $10 \mathrm{~min}$ at $0{ }^{\circ} \mathrm{C}$ in cold centrifuge. The supernatant was separated and used for various antioxidant enzyme estimations.

The levels of lipid peroxidation (LPO), speroxide dismutase (SOD), catalase (CAT), gutathione peroxidase (GPx) and gluathione (GSH) in liver and kidney tissues were estimated by ELISA method.

\section{Statistical analysis}

Data are presented as mean \pm standard deviation (SD), and were analyzed by one-way ANOVA followed by Tukey's multiple comparison using SPSS 17.0 software for Windows. Differences were considered statistically significant at $p<0.05$.

\section{RESULTS}

\section{Effect of AMBE on blood glucose and plasma insulin}

Fasting blood glucose levels in the normal control group of rats remained unchanged during the course of the experiment. In diabetic groups, level of fasting blood glucose was significantly ( $p$ $<0.01$ ) higher and the plasma insulin level was significantly decreased as compared to normal group. On the other hand, administration of AMBE for 30 days was found to lower the blood glucose and increase the insulin level significantly $(p<0.01)$ in a dose dependent manner when compared with control groups (Tables 1 and 2).

Table 1: Effect of AMBE on blood sugar level in rats (mean $\pm S D, n=10$ )

\begin{tabular}{lcccc}
\hline Group & Dose(mg/kg) & \multicolumn{3}{c}{ Blood sugar (mg/dL) } \\
\cline { 3 - 5 } & & Initial & Day 15 & Day 30 \\
\hline Negative & - & $67.15 \pm 2.63$ & $74.24 \pm 3.21$ & $75.39 \pm 2.83^{\prime \prime}$ \\
Control & - & $275.13 \pm 2.21$ & $311.18 \pm 3.54$ & $344.48 \pm 4.21$ \\
GLI & 1 & $283.48 \pm 2.27$ & $167.35 \pm 3.35^{\prime \prime}$ & $99.28 \pm 2.76^{\prime \prime}$ \\
AMBE-L & 40 & $292.37 \pm 3.22$ & $254.28 \pm 3.84^{\prime \prime}$ & $215.36 \pm 3.83^{\prime \prime}$ \\
AMBE-M & 80 & $286.92 \pm 2.48$ & $229.49 \pm 4.23^{\prime \prime}$ & $158.45 \pm 3.46^{\prime \prime}$ \\
AMBE-H & 160 & $276.74 \pm 2.59$ & $206.43 \pm 3.27^{* \pi}$ & $109.43 \pm 3.52^{* \pi}$
\end{tabular}

Key: $p<0.05, \quad p<0.01$ vs. control group. GLI: glibenclamide; AMBE-L: low dose of AMBE; AMBE-M: middle dose of $A M B E ; A M B E-H$ : high dose of $A M B E$ 
Table 2: Effect of AMBE on plasma insulin level in rats (mean $\pm S D, n=10$ )

\begin{tabular}{|c|c|c|c|c|}
\hline \multirow[t]{2}{*}{ Group } & \multirow[t]{2}{*}{ Dose(mg/kg) } & \multicolumn{3}{|c|}{ Plasma insulin (uU/ml) } \\
\hline & & Initial & Day15 & Day 30 \\
\hline Negative & - & $18.35 \pm 0.71$ & $17.14 \pm 0.86$ & $16.13 \pm 0.52$ \\
\hline Control & - & $6.22 \pm 0.65$ & $4.91 \pm 0.74$ & $3.84 \pm 0.68$ \\
\hline GLI & 1 & $5.87 \pm 0.57$ & $10.57 \pm 0.79^{n}$ & $11.86 \pm 0.75^{\wedge}$ \\
\hline AMBE-L & 40 & $6.41 \pm 0.53$ & $6.82 \pm 0.88^{\pi}$ & $7.62 \pm 0.81^{\pi}$ \\
\hline AMBE-M & 80 & $5.84 \pm 0.59$ & $10.43 \pm 0.91^{\pi \times}$ & $12.53 \pm 0.88^{\pi \pi}$ \\
\hline AMBE-H & 160 & $6.23 \pm 0.48$ & $11.78 \pm 0.83^{\pi x}$ & $13.96 \pm 0.74^{\pi \pi}$ \\
\hline
\end{tabular}

Key: ${ }^{*} P<0.05, \quad{ }^{* *} p<0.01$ vs. control group. GLI: glibenclamide; AMBE-L: low dose of AMBE; AMBE-M: middle dose of $A M B E ; A M B E-H$ : high dose of $A M B E$

\section{Effect of AMBE on biochemical parameters}

In order to examine the effect of AMBE on the regulation of biochemical parameters, creatinine and urea concentrations and total protein were studied to assess the renal function. STZ induced significant $(p<0.05)$ elevations in serum creatinine and urea levels and decrease in total protein when compared to normal group. However, treatment with different doses of AMBE significantly $(p<0.05)$ reduced serum creatinine and serum urea level and increased total protein when compared to those of diabetic control groups (Table 3).

\section{Effect of AMBE on oral glucose tolerance test (OGTT)}

The results indicated that the AMBE $(160 \mathrm{mg} / \mathrm{kg})$ and glibenclamide $(1 \mathrm{mg} / \mathrm{kg}$ ) reduced the blood glucose level (hyperglycemia due to glucose load $2 \mathrm{~g} / \mathrm{kg}$ p.o.) significantly $(p<0.05)$ after $120 \mathrm{~min}$ of oral administration, when compared to diabetic control (Table 4).

\section{Antioxidant status of rat liver and kidney tissue}

Oxidative stress assessment was performed by recording the activities of anti-oxidative enzymes i.e. catalase (CAT), Glutathioneperoxidase (GPx), superoxide dismutase (SOD), reduced glutathione (GSH) and lipid peroxidation. The diabetic rats showed significant $(p<0.05)$ increase in TBARS along with significantly decreased level of antioxidant enzymes i.e. CAT, GPx, GSH and SOD in hepatic and renal tissues. Treatment with AMBE significantly $(p<0.05)$ increased CAT, GPx, GSH and SOD in hepatic and renal tissues in diabetic rats. The increased level of TBARS was found to be reverted back to near normal status after treatment of AMBE $(p<$ 0.05 ) (Tables 5 and 6 ). The AMBE was found to possess antioxidant effect in a dose dependent manner.

Table 3: Effect of AMBE on biochemical parameters in rats (mean $\pm S D, n=10$ )

\begin{tabular}{|c|c|c|c|c|c|c|}
\hline Group & $\begin{array}{c}\text { Dose } \\
\text { (mg/kg) }\end{array}$ & $\begin{array}{c}\text { Hemoglobin } \\
\text { (mg/dL) }\end{array}$ & $\begin{array}{c}\text { Glycosylated } \\
\mathrm{Hb} \\
(\mathrm{Hb} \%)\end{array}$ & $\begin{array}{l}\text { Serum } \\
\text { creatinine } \\
(\mathrm{mg} / \mathrm{dL})\end{array}$ & $\begin{array}{c}\text { Serum } \\
\text { urea } \\
\text { (mg/dL) }\end{array}$ & $\begin{array}{c}\text { Total } \\
\text { proteins } \\
\text { (g/dL) }\end{array}$ \\
\hline Negative & - & $13.14 \pm 2.18$ & $6.62 \pm 0.79$ & $0.85 \pm 0.11$ & $33.87 \pm 1.76$ & $7.93 \pm 1.18$ \\
\hline Control & - & $8.12 \pm 1.22$ & $15.42 \pm 1.18$ & $2.31 \pm 0.28$ & $85.68 \pm 2.11$ & $4.31 \pm 1.37$ \\
\hline GLI & 1 & $10.34 \pm 2.48$ & $12.51 \pm 0.82$ & $0.89 \pm 0.29^{\circ}$ & $35.86 \pm 1.38^{\circ}$ & $7.41 \pm 1.42$ \\
\hline AMBE-L & 40 & $9.46 \pm 1.23^{\pi}$ & $12.37 \pm 0.88^{\pi}$ & $1.57 \pm 0.24^{\star}$ & $75.74 \pm 2.33^{x}$ & $6.43 \pm 1.21$ \\
\hline AMBE-M & 80 & $10.69 \pm 1.76^{\pi}$ & $9.79 \pm 0.78^{\pi}$ & $1.19 \pm 0.22^{*}$ & $60.78 \pm 1.67^{\approx}$ & $6.87 \pm 1.25$ \\
\hline AMBE-H & 160 & $12.64 \pm 1.47^{\star}$ & $8.05 \pm 0.81^{\star}$ & $0.86 \pm 0.29^{*}$ & $45.14 \pm 1.79^{x}$ & $7.48 \pm 1.39$ \\
\hline
\end{tabular}

Key: ${ }^{*} P<0.05, \quad{ }^{* *} p<0.01$ vs. control group. GLI: glibenclamide; AMBE-L: low dose of AMBE; AMBE-M: middle dose of $A M B E ; A M B E-H$ : high dose of $A M B E$

Table 4: Effect of AMBE on plasma insulin level in rats (mean $\pm S D, n=10$ )

\begin{tabular}{|c|c|c|c|c|c|c|}
\hline \multirow[t]{2}{*}{ Group } & \multirow{2}{*}{$\begin{array}{c}\text { Dose } \\
\text { (mg/kg) }\end{array}$} & \multicolumn{5}{|c|}{ Fasting blood glucose level (mg/dL) at (h) } \\
\hline & & Oh & $0.5 \mathrm{~h}$ & $1 \mathrm{~h}$ & $1.5 \mathrm{~h}$ & $2 \mathrm{~h}$ \\
\hline Negative & - & $91.7 \pm 0.4$ & $121.5 \pm 1.4$ & $127.4 \pm 1.2$ & $141.2 \pm 1.3$ & $145.2 \pm 1.4$ \\
\hline Control & - & $253.3 \pm 1.2$ & $259.1 \pm 0.7$ & $276.3 \pm 1.1$ & $294.3 \pm 1.1$ & $311.6 \pm 1.3$ \\
\hline GLI & 1 & $249.2 \pm 1.6$ & $258.2 \pm 1.1^{\pi}$ & $266.4 \pm 1.2^{x}$ & $281.3 \pm 1.5^{x}$ & $259.4 \pm 1.4^{\pi}$ \\
\hline AMBE-H & 160 & $252.5 \pm 1.4$ & $253.2 \pm 1.2^{x}$ & $267.2 \pm 1.2^{\star}$ & $288.4 \pm 1.2^{x}$ & $269.2 \pm 1.5^{x}$ \\
\hline
\end{tabular}

Key: ${ }^{*} p<0.05, \quad{ }^{* *} p<0.01$ vs. control group. GLI: glibenclamide; AMBE-H: high dose of AMBE 
Table 5: Effect of AMBE on anti-oxidative enzymes of liver in rats (mean $\pm S D, n=10$ )

\begin{tabular}{|c|c|c|c|c|c|c|}
\hline \multirow[b]{2}{*}{ Group } & \multirow[b]{2}{*}{$\begin{array}{c}\text { Dose } \\
\text { (mg/kg) }\end{array}$} & \multicolumn{5}{|c|}{ Liver } \\
\hline & & $\begin{array}{c}\text { SOD } \\
\text { (units/ } \\
\text { mg } \\
\text { protein) }\end{array}$ & $\begin{array}{c}\text { CAT } \\
\text { (mmol/ } \\
\mathrm{min} / \mathrm{mg} \\
\text { protein) }\end{array}$ & $\begin{array}{c}\text { GPX } \\
(\mathrm{mmol} / \\
\mathrm{min} / \mathrm{mg} \text { protein })\end{array}$ & $\begin{array}{c}\text { GSH } \\
(\mathrm{mM} / \\
100 \mathrm{~g} \text { tissue })\end{array}$ & $\begin{array}{c}\text { TBARS } \\
\text { (mmol/ } \\
100 \mathrm{~g} \text { tissue) }\end{array}$ \\
\hline Negative & - & $8.38 \pm 1.14$ & $84.86 \pm 2.14$ & $11.33 \pm 0.79$ & $55.23 \pm 1.79$ & $0.89 \pm 0.18$ \\
\hline Control & - & $3.62 \pm 0.22$ & $30.98 \pm 1.86$ & $5.79 \pm 0.68$ & $24.43 \pm 2.15$ & $2.13 \pm 0.16$ \\
\hline GLI & 1 & $6.19 \pm 0.33^{x}$ & $75.87 \pm 2.46^{\pi}$ & $10.15 \pm 1.28^{\pi}$ & $45.85 \pm 1.61^{\star}$ & $0.89 \pm 0.23^{\pi}$ \\
\hline AMBE-L & 40 & $5.76 \pm 0.22$ & $58.59 \pm 3.22$ & $7.79 \pm 1.12$ & $40.14 \pm 2.23^{n}$ & $1.49 \pm 0.38$ \\
\hline AMBE-M & 80 & $6.58 \pm 0.15^{\circ}$ & $67.94 \pm 2.85$ & $9.16 \pm 1.14$ & $46.25 \pm 2.65^{\wedge}$ & $1.25 \pm 0.39^{\circ}$ \\
\hline AMBE-H & 160 & $7.83 \pm 0.18^{x}$ & $83.25 \pm 3.14$ & $11.24 \pm 1.14^{\star}$ & $49.21 \pm 2.59^{\star}$ & $0.86 \pm 0.25^{x}$ \\
\hline
\end{tabular}

Key: ${ }^{*} P<0.05, \quad \stackrel{p}{* *} 0.01$ vs. control group. GLI: glibenclamide; AMBE-L: low dose of AMBE; AMBE-M: middle dose of AMBE; AMBE-H: high dose of AMBE.TBARS: thiobarbituric Acid Reactive Substances

Table 6: Effect of AMBE on anti-oxidative enzymes of kidney in rats (mean $\pm S D, n=10$ )

\begin{tabular}{|c|c|c|c|c|c|c|}
\hline \multirow[b]{2}{*}{ Group } & \multirow[b]{2}{*}{$\begin{array}{l}\text { Dose } \\
(\mathrm{mg} / \mathrm{kg})\end{array}$} & \multicolumn{5}{|c|}{ Kidney } \\
\hline & & $\begin{array}{c}\text { SOD } \\
\text { (units/ } \\
\text { mg } \\
\text { protein) }\end{array}$ & $\begin{array}{c}\text { CAT } \\
\text { (mmol/ } \\
\text { min/mg } \\
\text { protein) }\end{array}$ & $\begin{array}{c}\text { GPX } \\
(\mathrm{mmol} / \\
\mathrm{min} / \mathrm{mg} \text { protein })\end{array}$ & $\begin{array}{c}\text { GSH } \\
(\mathrm{mM} / \\
100 \mathrm{~g} \text { tissue })\end{array}$ & $\begin{array}{c}\text { TBARS } \\
(\mathrm{mmol} / \\
100 \mathrm{~g} \text { tissue })\end{array}$ \\
\hline Negative & - & $16.24 \pm 0.41$ & $73.27 \pm 2.53$ & $14.31 \pm 1.23$ & $36.97 \pm 1.38$ & $1.47 \pm 0.22$ \\
\hline Control & - & $8.23 \pm 0.21$ & $48.48 \pm 2.74$ & $6.67 \pm 0.84$ & $24.17 \pm 1.62$ & $2.59 \pm 0.17$ \\
\hline GLI & 1 & $13.06 \pm 0.32$ & $70.46 \pm 2.49^{\circ}$ & $11.47 \pm 0.85$ & $34.24 \pm 1.73^{\prime}$ & $1.85 \pm 0.26$ \\
\hline AMBE-L & 40 & $10.18 \pm 0.48$ & $62.25 \pm 3.27$ & $10.23 \pm 1.38$ & $30.17 \pm 1.45$ & $1.88 \pm 0.52$ \\
\hline AMBE-M & 80 & $11.94 \pm 0.57^{\pi}$ & $68.86 \pm 3.39^{\star}$ & $11.48 \pm 1.21^{\star}$ & $32.73 \pm 1.36$ & $1.69 \pm 0.45^{\pi}$ \\
\hline AMBE-H & 160 & $14.13 \pm 0.49^{\pi}$ & $72.27 \pm 3.21^{\pi}$ & $11.96 \pm 1.16$ & $34.56 \pm 1.14^{\pi}$ & $1.52 \pm 0.48^{\pi}$ \\
\hline
\end{tabular}

Key: ${ }^{*} P<0.05, \quad{ }^{* *} p<0.01$ vs. control group. GLI: glibenclamide; AMBE-L: low dose of AMBE; AMBE-M: middle dose of AMBE; AMBE-H: high dose of AMBE.TBARS: thiobarbituric acid reactive substances

\section{DISCUSSION}

The continuous treatment of AMBE for a period of 30 days produced a significant $(p<0.05)$ decrease in blood glucose levels in diabetic rats which is comparable to that of standard and diabetic control group. An increase in blood glucose seen in the oral glucose tolerance test (OGTT) was significantly greater in the diabetic rats than in the non-diabetic rats. The level of plasma insulin increased in non-diabetic rats, but unchanged in diabetic rats. Oral administration of AMBE $80 \mathrm{mg} / \mathrm{kg}$ significantly improved the impaired glucose tolerance in the diabetic rats with change in plasma insulin level. Considering the above result, the hypoglycemic effect of the plant may involve an insulin-like action i.e., acting at peripheral level to increase cellular glucose uptake or increase glycogenesis.

A number of plants have been shown to exert hypoglycemic activity through stimulation of insulin release [15] like glibenclamide that has been reported to enhance the activity of beta cells of pancreas resulting in increased secretion of large amount of insulin which in turn brings down blood glucose level. It is assumed that the extract of Astragalus membranaceus may be responsible for stimulation of insulin and the observed restoration of metabolic activity.
The diabetic hyperglycemia induces elevation of the serum level of urea and creatinine which has been considered as significant markers of renal dysfunction [16]. An increase in serum level of urea and creatinine levels in STZ-diabetic rats may indicate diminished ability of the kidney to filter these waste products from the blood and excrete them in the urine. On the other hand, the results indicate that treatment of diabetic group with Astragalus membranaceus (Fisch.) Bunge. extract significantly reduced serum urea and creatinine level. Based on these findings, the extract of this plant may enhance the ability of the kidney to remove these waste products from the blood, as indicated by a protective effect on the kidney of diabetic rats.

Diabetes is strongly co-related with oxidative stress induction. Lipid peroxidation is one of the characteristic features of diabetes mellitus. Measurement of plasma thiobarbituric acid reactive substances (TBARS) was used as an index of lipid peroxidation and it helps to assess the extent of tissue damage [17]. Several studies have reported an increase in TBARS and hydroperoxides in plasma, liver and kidney in experimental diabetes mellitus [18]. The result of the present study showed that Astragalus membranaceus extract significantly $(p<0.05)$ 
decreased TBARS level and reduced the risk of tissue damage.

Oxidative stress in diabetes is coupled to a decrease in antioxidant status, which can increase the deleterious effects of free radicals. SOD and CAT are the two major scavenging enzymes that remove free radicals. Reduced activities of these antioxidant enzyme in liver, kidney and pancreas tissues have been observed in diabetic rats and this activity may result in a number of deleterious effects due to accumulation of superoxide anion (O) and hydrogen peroxide $\left(\mathrm{H}_{2} \mathrm{O}_{2}\right)$, which in turn generate hydroxyl radicals $(\mathrm{OH})$, resulting in initiation and propagation of LPO. SOD protects from oxygen free radicals by catalyzing the removal of superoxide radical, which damage the membrane and biological structures.

Catalase has been shown to be responsible for the detoxification of $\mathrm{H}_{2} \mathrm{O}_{2}$, and protected the tissues from highly reactive hydroxyl radicals [19]. The decrease in CAT activity could have resulted from in activation by glycation of enzyme [20]. In the present study, extract treated groups showed a significant increase in the hepatic and renal SOD and CAT activities of the diabetic rats. This means that the extracts can reduce the potential glycation of enzymes or they may reduce reactive oxygen free radicals and improve the activities of antioxidant enzymes. This result clearly shows that Astragalus membranaceus (Fisch.) Bunge. contains a free radical scavenging activity, which could exert a beneficial action against pathological alteration caused by the presence of superoxide radicals and hydrogen peroxide radical.

\section{CONCLUSION}

This study shows that Astragalus membranaceus (Fisch.) Bunge. extract possesses potent antioxidant activity which may be responsible for its hypoglycemic property. Further pharmacological and biochemical investigations are underway to determine the active constituents responsible for its antidiabetic activity and to elucidate its mechanism of action.

\section{DECLARATIONS}

\section{Conflict of Interest}

No conflict of interest associated with this work.

\section{Contribution of Authors}

The authors declare that this work was done by the authors named in this article and all liabilities pertaining to claims relating to the content of this article will be borne by them.

\section{REFERENCES}

1. Klein G, Kim J, Himmeldirk K, Cao, Y, Chen X. Antidiabetes and antiobesity activity of Lagerstroemia speciosa. Evidence-based Complement. Altern. Med. 2007; 4: 401-407.

2. Chakraborty $U$, Das $H$. Antidiabetic and antioxidant activities of Cinnamomum tamala leaf extracts in stztreated diabetic rats. Glo J Biotech Biol 2010; 5: 12-18.

3. West IC. Radicals and oxidative stress in diabetes. Diabetic Med. 2000; 17:171-180.

4. Baynes JW. Role of oxidative stress in development of complications in diabetes. Diabetes 1991; 40: 405-412.

5. Oberley LW. Free radicals and diabetes. Free Radical Biology \& Medicine 1988; 5: 113-124.

6. Jacob RA. The integrated antioxidant system. Nutrition Research 1995; 15: 755-767.

7. Baynes JW. Reactive oxygen in the etiology and complications of diabetes. In: loannides $C$, Flatt $P R$ (Eds), Drug, Diet and Disease: Mechanistic Approach to Diabetes, vol. 2. Ellis Horwood Limited, Hertfordshire, 1995. 203-231p.

8. Sha $W J, L u H$. The research progress of astragalus in regulating blood glucose steady state of diabetes patients. Int J Trad Chin Med. 2015; 37: 87-89.

9. Gao Y, Guo J, Ren SP. Effect of Radix Astragali on blood glucose, TG, HDL-C, LDL-C and insulin levels in diabetic rats. Chin. J Ger. 2008; 28: 1676-1677.

10. European Commission [homepage on the internet]. Directive 2010/63/EU on the protection of animals used for scientific purposes [cited 2013 Jan 16]. Availablefrom:http://ec.europa.eu/environment/chemical s/lab_animals/legislation_en.htm.

11. Hemalatha S, Wahi AK, Singh PN, Chansouria JP. Hypoglycemic activity of Withania Coaculants Dunal in streptozotocin induced diabetic rats. J Ethnopharmacol 2004; 93: 261-264.

12. Balasubramaian $R$, Kasiappan $R$, Vengidusamy $N$, Muthusamy K, Sorimuthu S. Protective effect of macrocyclic binuclear oxovanadium complex on oxidative stress in pancreas of streptozotocin induced diabetic rats. Chemico-Biological Interaction 2004; 149: 9-21.

13. Burcelin R, Eddouks M, Maury J, Kande J, Assan R, Girard J. Excessive glucose production, rather than insulin resistance, account for hyperglycemia in recent onset streptozocin-diabetic rats. Diabetologia 1995; 35: 283-290.

14. Sasaki T, Matzy S, Sonal A. Effect of acetic acid concentration on the colour reaction in the O-toluidine 
boric acid method for blood glucose estimation. Rinsh Kagaku 1972; 1: 346-353.

15. Prince PSM, Menon VP. Hypoglycemic and other related action of Tinospora cordifolia roots in alloxan rats. $J$ Ethnopharmacol 2000; 70: 19-25.

16. Almdal TP, Vilstrup $H$. Strict insulin treatment normalizes the organic nitrogen contents and the capacity of urea- $N$ synthesis in experimental diabetes in rats. Diabetologia 1988; 31: 114-118.

17. Gutteridge JMC. Lipid peroxidation and antioxidants as biomarkers of tissue damage. Clinical Chem.1995; 14: 1819-1828.
18. Ananthan R, Latha M, Pari L, Baskar C, Narmatha V. Modulatory effects of Gymnema montanum leaf extract on alloxan induced oxidative stress in wistar rats. Nutrition 2004; 20: 280-285.

19. Mahboob M, Rahman MF, Grover P. Serum lipid peroxidation and antioxidant enzyme levels in male and female diabetic patients. Singapore Med J 2005; 46: 322-324.

20. Yan H, Harding JJ. Glycation-induced inactivation and loss of antigenicity of catalase and superoxide dismutase. Biochemical J 1997; 328: 599-600. 